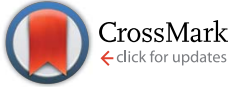

Cite this: RSC Adv., 2014, 4, 40043

DOI: $10.1039 / c 4 r a 90007 c$

www.rsc.org/advances

\title{
Correction: Development and evaluation of carbon and binder loading in low-cost activated carbon cathodes for air-cathode microbial fuel cells
}

\author{
Bin Wei, ${ }^{a}$ Justin C. Tokash, ${ }^{a}$ Guang Chen, ${ }^{\text {ab }}$ Michael A. Hickner ${ }^{\mathrm{b}}$ and Bruce E. Logan ${ }^{\star a}$
}

Correction for 'Development and evaluation of carbon and binder loading in low-cost activated carbon cathodes for air-cathode microbial fuel cells' by Bin Wei et al., RSC Adv., 2012, 2, 12751-12758.

In the study by Wei et al. it was stated that cathodes made using an activated carbon catalyst "were made with the following loadings (projected area of $7 \mathrm{~cm}^{2}$ ): 7, 11, 14, 28, 43, 100, $171 \mathrm{mg} \mathrm{cm}$.". However, the $7 \mathrm{~cm}^{2}$ area was the exposed (working) projected area of the cathode, and not the area of the cathode containing the activated carbon. Therefore, the loadings were incorrectly reported. The activated carbon was applied to a surface area of $11.3 \mathrm{~cm}^{2}$, with only $7 \mathrm{~cm}^{2}$ of the cathode exposed to solution or air. These loadings should all be reduced by a factor of 0.62 , and thus the correct loadings are: 4, 7, 9, 17, 27, $62,106 \mathrm{mg}$ $\mathrm{cm}^{-2}$. The first sentence of the abstract indicating that the range of applied carbon was " $43-171 \mathrm{mg} \mathrm{cm}$ ", should have included the lowest activated carbon loading, and the correct range is now " $4-106 \mathrm{mg} \mathrm{cm}^{-2}$ ". The findings and interpretation of the results were not affected by these errors.

The Royal Society of Chemistry apologises for these errors and any consequent inconvenience to authors and readers. 